\title{
Langerhans Cell Histiocytosis, Polystotic
}

National Cancer Institute

\section{Source}

National Cancer Institute. Langerhans Cell Histiocytosis, Polystotic. NCI Thesaurus. Code C150702.

Langerhans cell histiocytosis presenting with multiple sites of involvement. 